\title{
MAPPING OF THE DETERMINANTS OF SATISFACTION WITH LIFE OF PORTUGUESE SENIORS: PROPOSALS FOR PREVENTIVE INTERVENTION AT AN ORGANIZATIONAL LEVEL
}

\author{
Ana Pinto \\ Universidade de Coimbra, Faculdade de Ciencias e Tecnologia, Centre of Business and Economics Research \\ (CEBER), e, Instituto Politecnico de Coimbra, Escola Superior de Educação, Nucleo de Investigação em \\ Ciencias Sociais e Humanas (NICSH) \\ ana.pinto@dem.uc.pt \\ Aida Isabel Tavares \\ ISEG, Lisbon School of Economics and Management, Lisbon-Portugal \\ CEISUC, Centre of Studies and Research in Health of the University of Coimbra \\ Carla Carvalho \\ Universidade de Coimbra, Faculdade de Psicologia e Ciencias da Educação, Centro de Investigação em \\ Neuropsicologia e Intervenção Cognitivo Comportamental (CINEICC) \\ Paulo Santos Costa \\ Escola Superior de Enfermagem de Coimbra \\ Pedro Parreira \\ Escola Superior de Enfermagem de Coimbra
}

Recepción Artículo: 13 mayo 2021

Admisión Evaluación: 13 mayo 2021

Informe Evaluador 1: 26 mayo 2021

Informe Evaluador 2: 28 mayo 2021

Aprobación Publicación: 01 junio 2021

\section{ABSTRACT}

This study focuses on the impact of demographic, socioeconomic, geographic and health determinants on Portuguese seniors' life satisfaction. The aim of this research is, therefore, to map the determinants of satisfaction with the life of the Portuguese seniors at a national and regional level. This knowledge brings insights to improve quality of life, starting with prevention in their active life (organizational level). We used data collected by the National Health Survey of 2014 and estimated a linear OLS regression both for Portugal and its regions. The main results show that determinants that contribute positively to the level of satisfaction with life are: marital status of being "married"; higher levels of education; higher levels of income; being men and people living in rural areas. The determinant that contributed negatively to the level of satisfaction with life is the existence of chronic diseases. The results at the regional level maintain the trends observed at the country level, showing income and chronic diseases as determinants that have an impact on life satisfaction in all regions. A general profile of the Portuguese seniors is provided for the country and by region, as well as proposals, generic and transversal, at the organizational level are outlined.

Keywords: determinants of life satisfaction; profile of Portuguese seniors; Portuguese regions; preventive intervention 


\section{RESUMEN}

Mapeo de los determinantes de la satisfacción con la vida de los mayores portugueses: propuestas de intervención preventiva a nivel organizativo. Este estudio se centra en el impacto de los determinantes demográficos, socioeconómicos, geográficos y de salud en la satisfacción con la vida de los mayores portugueses. El objetivo de esta investigación es, por tanto, mapear los determinantes de la satisfacción con la vida de los mayores portugueses a nivel nacional y regional. Este conocimiento aporta ideas para mejorar la calidad de vida, empezando por la prevención en su vida activa (nivel organizativo). Utilizamos datos recogidos por la Encuesta Nacional de Salud de 2014 y estimamos una regresión lineal OLS tanto para Portugal como para sus regiones. Los principales resultados muestran que los determinantes que contribuyen positivamente al nivel de satisfacción con la vida son: el estado civil de estar "casado"; los niveles más altos de educación; Ios niveles más altos de ingresos; ser hombres y las personas que viven en zonas rurales. El determinante que contribuyó negativamente al nivel de satisfacción con la vida es la existencia de enfermedades crónicas. Los resultados a nivel regional mantienen las tendencias observadas a nivel de país, mostrando la renta y las enfermedades crónicas como determinantes que inciden en la satisfacción con la vida en todas las regiones. Se ofrece un perfil general de los mayores portugueses para el país y por regiones, así como se esbozan propuestas, genéricas y transversales, a nivel organizativo.

Palabras clave: determinantes de la satisfacción vital; perfil de los mayores portugueses; regiones portuguesas; intervención preventiva

\section{INTRODUCTION}

In the literature, Life Satisfaction (LS) often emerges as synonymous with Subjective Well-being (SWB). Both concepts address general well-being, which is assessed through the dimensions of $L S$ and Happiness, which are differentiated by the specificity of the involved psychological processes (Mónica et al., 2019). Embedded within the field of positive psychology (Dienner et al., 1999), SWB is a multifaceted phenomenon that is determined by two closely related components: the emotional and cognitive ones. The latter, described as satisfaction with life, concerns the way an individual perceives the quality of his/her life basing on a unique set of own criteria. A global assessment of one's life is crucial, not purely the satisfaction associated with specific achievements or life areas (Judge \& Watanabe,1993). Satisfaction with life constitutes the result of a long-term reflection as opposed to not a short-term one (Pavot \& Diener, 1993). It is the assessment of life as a whole and it is relatively permanent as such.

Concrete aspects of daily life, such as family, friends, professional status and social status are part of the subjective assessment of satisfaction (Silva, 1998). Satisfaction with life indeed refers to a global assessment, but we cannot deny that the area of work occupies a fundamental role at the time of its assessment. We spend a large part of our lives working actively in organizations. Eurostat data shows the increasing trend in expected duration of working life in the European Union (EU). Compared to 2018, data for the past year show that the population above 15 years of age may spend an additional 2.5 months working, resulting in a working life with an expected duration of 35.9 years. The Portuguese are among the countries where the active population is expected to spend more years of their life working. While the EU average is at 35.9 years, in Portugal the employment context is expected to last almost three more years.

Different studies in the literature point to the justification of the relationship between satisfaction with life and satisfaction with work (Judge \& Watanabe, 1993; Rain et al., 1991, Unanue et al., 2017), with evidence of moderate and positive correlations between these two variables (Judge \& Watanabe, 1993; Schaubroeck, et al., 1992). Researchers, in attempting to explain the connection between job and life satisfaction, have proposed three theoretical models. These comprise the spillover, compensation and segmentation perspectives (Loscocco \& Roschelle, 1991). In this study, we sustain the spillover perspective model for this positive relationship (Bowling et al., 2010). This perspective suggests that satisfaction in one domain of an individual s life extends into other areas. This may be from life to job satisfaction or from job to satisfaction. A positive relationship between the two 
is implied in this model. That is, employees who are satisfied at work are also believed to be happy in their nonwork activities, while employees dissatisfied at work are believed to be unhappy in their non-work activities.

Portugal is the fifth most aged country in the world. It is an unquestionable fact that the Portuguese population is ageing. The ageing rate - number of individuals aged 65 years and over for every 100 under 15 years old - went from 98.8 in 2000 to 157.4 in 2018 (INE, 2020; PORDATA, 2020). Portugal is expected to have the biggest ageing population in the EU by 2050 (EUROSTAT, 2020).

\section{AIM OF THE RESEARCH}

If ageing is irreversible, its degree can be very different, with public policies playing a very important role in this process. A few measures are already being applied to mitigate the ageing of the Portuguese population (e.g., the progressive extension of the period of paid parental leave; retention of talent from Portuguese professionals in Portugal; promotion of the country's attractiveness as a permanent place of residence for others cultures). However, these measures do not reverse it. There is a need for a commitment at the level of Portuguese organizations that is based on a package of measures, of gradual implementation, that allows us to prepare for an increase in the future quality of life of our older adults because it is inevitable that Portuguese society becomes progressively more grey. The increasing population of older adults has generated a need to investigate this area so that we can be responsive to this growing segment of Portuguese society. The essential purpose of this study is to contribute further to this effort. This research study aims to map the determinants of satisfaction with the life of the Portuguese older adults in the country and in the regions defined by the NUTII (2004) - North, Centre, Lisbon, Alentejo, Algarve, Azores and Madeira - to suggest general preventive intervention proposals at the organizational level.

\section{DATA AND SAMPLE}

Data used for the analysis performed in this study is collected by the National Health Survey (NHS) of 2014 (INE, 2016). This survey is a community-based cross-sectional study. Data were collected following a multistage stratified and cluster sampling. The obtained sample represents the Portuguese population. The survey was implemented in the whole country between September and December 2014, and it included 18.204 people aged 15 years or over, who are not institutionalized. The questions in the survey covered four thematic areas: health status, healthcare, health determinants, and income and health expenses. The NHS 2014 is a survey harmonized and regulated at an EU level [Commission Regulation (EU) No 141/2013]. Our sample includes all respondents older than 65 years $(n=5.701)$.

\section{METHOD}

\section{Variables}

The dependent variable of this study is satisfaction with life, obtained from the question in the National Health Survey "I am satisfied with my life". This variable ranges from 1 to 7 , with 1 being the level of least satisfaction ("totally disagree") and 7 the level of highest satisfaction ("totally agreeing"). A set of demographic, socioeconomic, geographic and health characteristics comprised the independent variables (Table 2). 
Table 1. Description of independent variables.

\begin{tabular}{ll}
$\begin{array}{l}\text { Group of } \\
\text { Variables }\end{array}$ & Independent Variables (description) \\
\hline $\begin{array}{l}\text { Demograph } \\
\text { ic variables }\end{array}$ & $\begin{array}{l}\text { Sex: female; male. } \\
\text { Age: grouped in five classes }(65-69,70-74,75-79,80- \\
84, \text { and }>85 \text { years old). }\end{array}$
\end{tabular}

Education: grouped in five levels corresponding to the number of complete schooling years and levels, $0,6,9$, 12,15 , and 17 ( 0 means no schooling and 17 means university degree). Variable treated as continuous.

\begin{tabular}{|c|c|}
\hline \multirow{3}{*}{$\begin{array}{l}\text { Socio- } \\
\text { economic } \\
\text { variables }\end{array}$} & Alone: Lives alone. \\
\hline & $\begin{array}{l}\text { Marital status: Single; Married; Divorced; Widow } \\
\text { (Reference category). }\end{array}$ \\
\hline & $\begin{array}{l}\text { Income: grouped in five classes which represent the } \\
\text { quintile of net monthly income per equivalent adult. } \\
\text { Variable treated as continuous. }\end{array}$ \\
\hline $\begin{array}{l}\text { Health } \\
\text { Variables }\end{array}$ & $\begin{array}{l}\text { Chronic diseases: yes, at least one diagnosed condition; } \\
\text { no diagnose of chronic disease. }\end{array}$ \\
\hline \multirow{3}{*}{$\begin{array}{l}\text { Geographic } \\
\text { variables }\end{array}$} & $\begin{array}{l}\text { Degree of urbanization: measures the degree of } \\
\text { urbanization where individuals live. } \\
\text { - Urban (dummy variable where urban means } \\
\text { geographical areas with more than } 5,000 \text { inhabitants } \\
\text { and a population density higher than } 500 \text { inhabitants } \\
\text { per } \mathrm{Km}^{2)} \text {. }\end{array}$ \\
\hline & $\begin{array}{l}\text { - Rural (dummy variable where rural means } \\
\text { geographical areas with less than } 2,000 \text { inhabitants and } \\
\text { a population density lower than } 100 \text { inhabitants per } \\
\mathrm{Km}^{2} \text { ). } \\
\text { - Moderate (reference category, defined in-between } \\
\text { urban and rural areas defined above). }\end{array}$ \\
\hline & $\begin{array}{l}\text { Region: North (reference category); Centre; Lisbon; } \\
\text { Alentejo; Algarve; Azores; Madeira. }\end{array}$ \\
\hline
\end{tabular}

Statistical analysisA descriptive statistical analysis of the independent and dependent variables by region was carried out to define a profile for each region. Then, a linear ordinary least squares (OLS) regression was estimated for the country and for each region. Regression for country included the set of independent variables considered initially. The regressions for each region exclude the non-significant independent variables found previously in the regression for country. Analyses were conducted with Stata version 15 (StataCorp LP, College Station, Texas, USA). 


\section{RESULTS}

\section{Results of descriptive analysis}

To outline geographical profiles, the results obtained by region are presented in Table 2. The determinants of satisfaction (gender, marital status, education level, income level, living alone, urbanization and chronic diseases) are described, as well as satisfaction with the life of seniors for Portuguese regions.

Table 2. Determinants of satisfaction and satisfaction with life for NUTS II

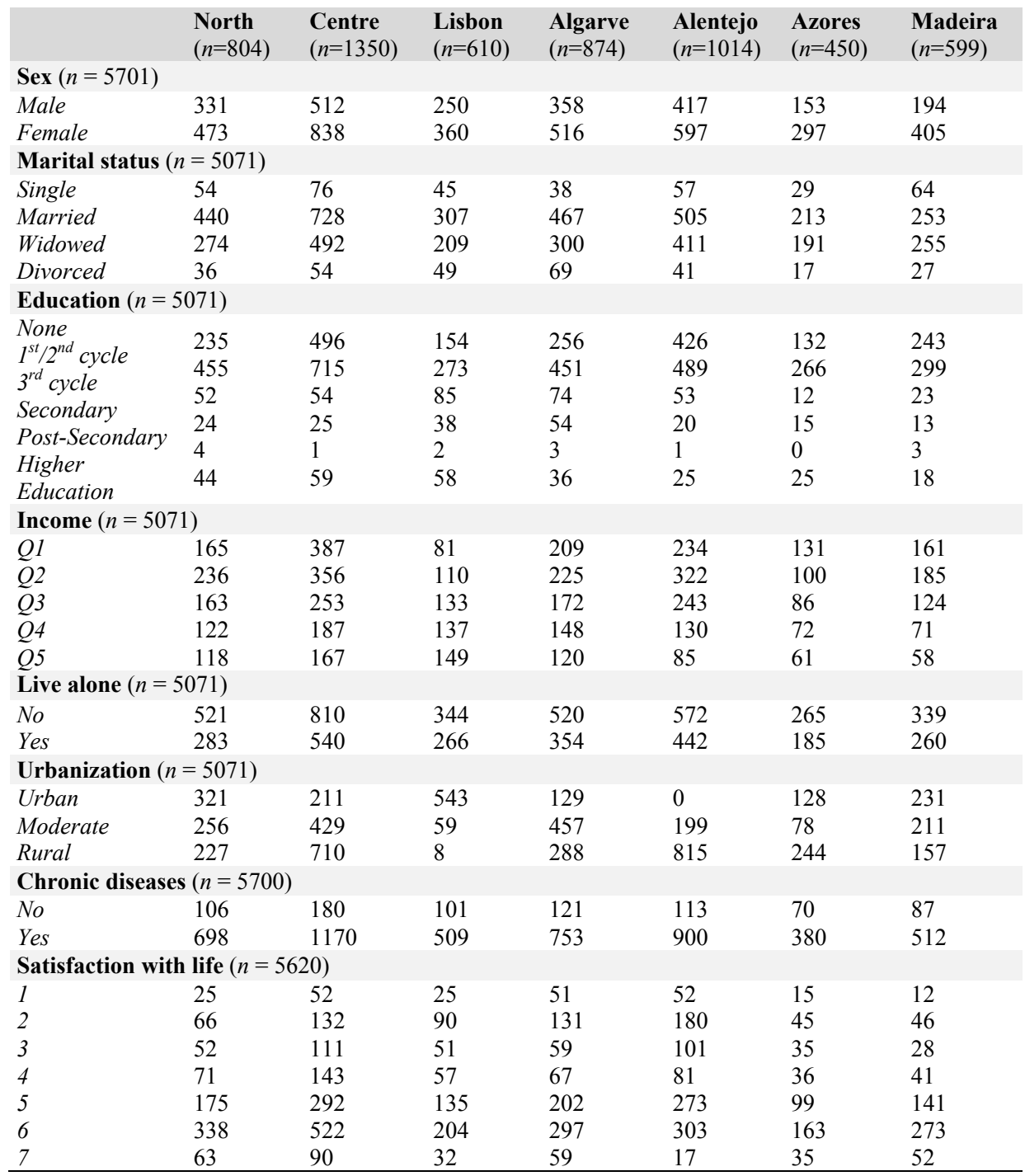




\section{MAPPING OF THE DETERMINANTS OF SATISFACTION WITH LIFE OF PORTUGUESE SENIORS:}

PROPOSALS FOR PREVENTIVE INTERVENTION AT AN ORGANIZATIONAL LEVEL

\section{Estimation results}

The results of the estimation of a linear model for the country are shown in Table 3. The geographic region with the highest levels of satisfaction with life was Madeira Islands, followed by North, Azores Islands and Centre. Regions with the lowest reported satisfaction with life were Algarve, Lisbon and Alentejo.

Data indicates that being single, married or widowed contributes positively to satisfaction with life. Although married participants displayed higher scores compared to the other subgroups- Higher levels of education or income are also associated with higher levels of satisfaction. On the overall, male participants and living in rural areas tended to have higher levels of satisfaction with life. Results also highlighted that suffering from chronic diseases has a reducing effect on satisfaction with life. Additionally, age, living in urban spaces and living alone did not relate to satisfaction with life on a statistically significant level.

Table 3. Estimation results.

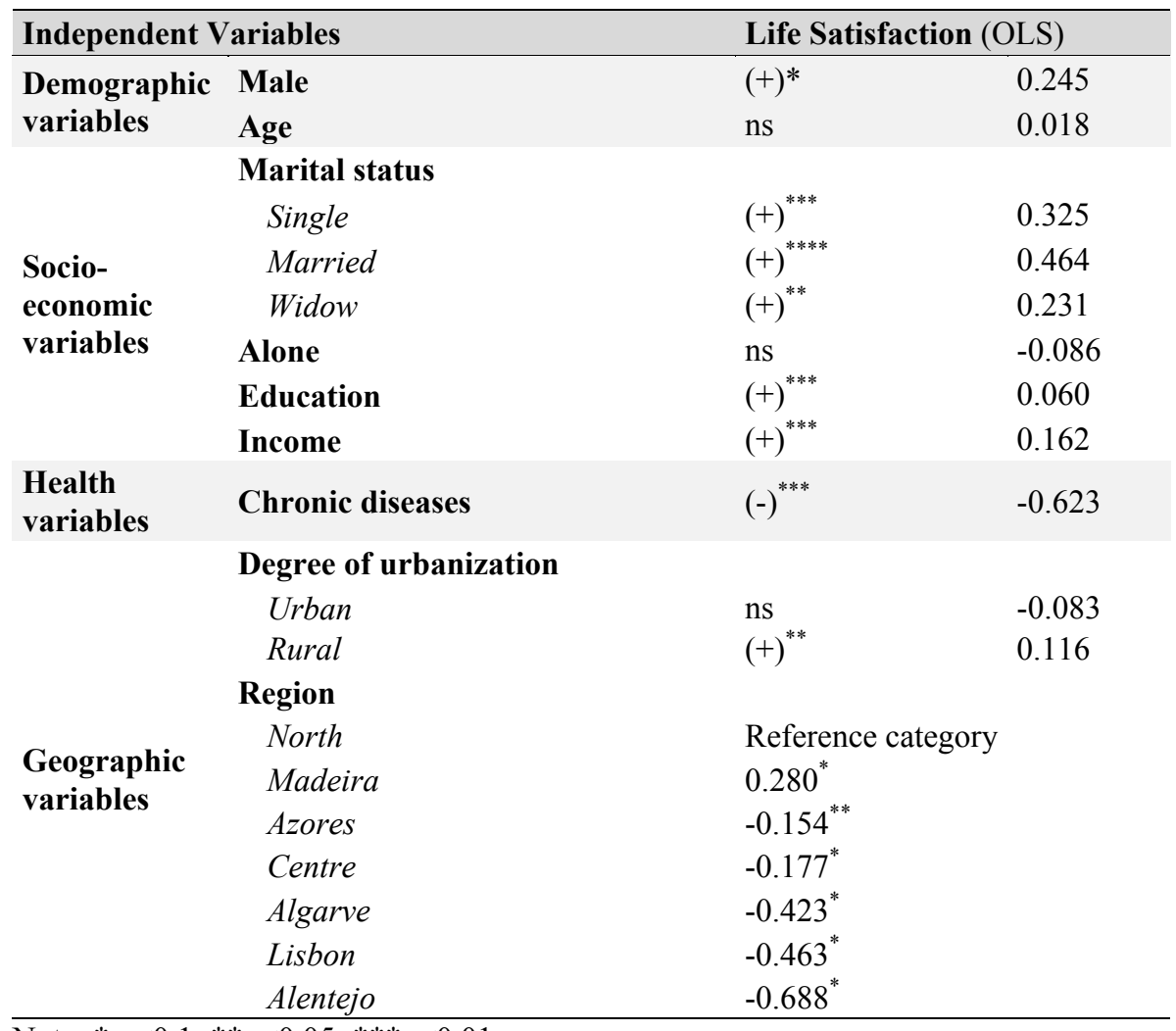

The results of the estimation of a linear model for each region are shown in Table 4. The estimated coefficients in shaded areas have no statistical significance. The determinants that have an impact on satisfaction with life in all regions are income and chronic diseases. While income contributes positively to satisfaction with life, chronic illnesses have the opposite effect. On the other hand, the effect of income is identical between regions, but chronic diseases has a more intense negative effect in Lisbon and less intense in Madeira. 
The estimated coefficients with statistical significance vary between the regions, maintaining, however, the trends previously observed (Table 3). Nonetheless, some results worth to be highlighted: i) the greatest influence of being married is found in the Alentejo region; ii) men in the Azores tend to have higher levels of satisfaction with life than in any other region of the country and it is the factor that most contributes to satisfaction with life in the region; iii) living in rural areas is only relevant in the North and Madeira.

Table 4. Estimation results for regions.

\begin{tabular}{|c|c|c|c|c|c|c|c|}
\hline Variables & North & Algarve & Centre & Lisbon & Alentejo & Azores & Madeira \\
\hline Male & $.262 * *$ & $.329 * * *$ & $.254 * * *$ & $.322 * *$ & $.204 *$ & $.482 * * *$ & .001 \\
\hline Single & $.555^{*}$ & .209 & .444 & .398 & .374 & -.603 & $.591 *$ \\
\hline Married & $.650 * *$ & $.450 * *$ & $.581 * * *$ & .310 & $.895 * * *$ & -.201 & $.626^{* *}$ \\
\hline Widow & $.448 *$ & .352 & .150 & -.046 & $.614 * *$ & -.629 & $.494 *$ \\
\hline Education & .014 & $.113 *$ & -.010 & .066 & $.110^{*}$ & -.046 & $.129 * *$ \\
\hline Income & $.170 * * *$ & $.177 * * *$ & $.153 * * *$ & $.170 * * *$ & $.180 * * *$ & $.119^{* *}$ & $.164 * * *$ \\
\hline Rural & $.217^{*}$ & .186 & .026 & .345 & .043 & .030 & $.473 * * *$ \\
\hline $\begin{array}{l}\text { Chronic } \\
\text { Diseases }\end{array}$ & $-583 * * *$ & $-663 * * *$ & $-506 * * *$ & $-947 * * *$ & $-775 * * *$ & $-585 * * *$ & $-.388 * *$ \\
\hline
\end{tabular}

\section{DISCUSSION}

This study focused on mapping the determinants of satisfaction with the life of Portuguese older adults residing in the country, with an overall and per geographical region analysis. The results obtained assisted in the development of a general preventive intervention that could be successfully implemented at an organizational level to enhance current trends in satisfaction with life in Portugal.

By analyzing the data, it appears that the greater/better the retirement of a senior, the greater the degree of satisfaction with life. In Portugal, due to social and economic constraints, it appears that there is a very significant fringe of the active population that is still paid with the national minimum wage of 635 euros (DGERT/MTSSS). Another fact that must be reconsidered is that women are more penalized regarding their remuneration. In Portugal, as well as in the EU, evidence suggests that women are still underpaid comparing to male peers even if both are performing the same job (with the same level of mental and physical demands). In fact, in 2018, the gender per job wage difference was around $14 \%$ in Portugal (CIG, 2020). Components of a social and cultural nature must be tackled by our organizations. There are already some Portuguese organizations, although few and mainly from the private sector, that remunerate their workers in an equal way regardless of their gender. There is still room for improvement in terms of equity of opportunities, remuneration and growth of women in Portuguese organizations. Given that living in rural areas has also been identified as positively associated with life satisfaction, the possibility in some companies to settle in these areas (when applicable) and the use of teleworking is something that deserves the attention of managers.

At a social and cultural level, it appears that the balance between family life and professional life is more out of step for women. In several social and cultural settings, and with their entry in the job market, women have experience a greater sense of burden associated with the pressure to combine their professional role while also being responsible for domestic and maternal duties. It is true that some efforts have been made to mitigate this burden, but it is still a long way from becoming egalitarian. Betting on equal opportunities for promotion within an organization is closely related to the balance between family and professional life. Most Portuguese CEOs are men. The woman often ends up giving up her professional life in favor of her family life. Cultural conditions and the pressure placed on the role of women in organizations and family life must be rethought. Given that higher levels of education were also identified as a determinant of satisfaction with life, Portuguese organizations should acti-

International Journal of Developmental and Educational Psychology 
vely implement paid training actions. Such training actions must be developed in two main forms: a) general training actions, accessible to all employees, regardless of role or stature; b) tailored training sessions, designed to boost the workers' competences in a specific field. Recurrent training sessions are widely discussed in the literature as a catalyst of the workers' own confidence and motivation to work, leading to more cost-efficient results and retaining rates.

Finally, urgent measures must be implemented that focus on the prevention of psychosocial risks in our organizations. The possibility of decreasing the onset of chronic diseases is associated with an increase in life satisfaction (Dong et al., 2020). Thus, Portuguese organizations must strive to implement preventive occupational health policies, that include routine check-ups by licensed healthcare professionals; flexible breaks and equipped space for short-duration exercises (e.g., stretching, cardio); healthy meals in the organization's canteen/bar and vending machines (or provide free healthy snacks and water fountains); recurrent promotional leaflets, e-mail newsletters or posters that promote healthy lifestyle tips. Additionally, Portuguese organizations must search for successful experiences in other international settings, such as the development of organizational/corporate group activities or retreats that boost workers morale and positive work relationships, while promoting healthy lifestyles. Given that being married was also a significant determinant found in this study, we propose that such organizational/corporate activities actively include the workers' relatives, creating a sense of community that expands beyond the organization's stakeholders and increasing their overall sense of satisfaction with life.

\section{CONCLUSIONS}

This study shows that being married, having a high education level and income, as well as living in a rural area is positively associated with greater satisfaction with life scores amongst Portuguese older adults. Moreover, we found that such determinants follow a nationwide pattern. Conversely, the presence of chronic diseases negatively impacts older adults' satisfaction with life scores.

Due to the relevance that professional life represents in one's life, contributing to the individual's social, economic and mental balance, as well as to his/her sense of identity, we briefly propose a series of preventive measures that must be implemented at an organizational level in order to boost overall satisfaction with life scores from an active ageing onwards, such as: overall increase in wages; egalitarian wages and promotions regardless of gender; active implementation of occupational health approaches to mitigate work-related biopsychosocial risks; and investment in human capital through training.

\section{BIBLIOGRAPHIC REFERENCES}

Bowling, N.A., Eschleman, K.J., \& Wang, Q. (2010). A meta-analytic examination of the relationship between job satisfaction and subjective well-being. Journal of Occupational and Organizational Psychology, 83, 915-934.

CIG (2020). Governmental Commission for Citizenship and Gender equality. https://www.cig.gov.pt/2019/07/1aedicao-do-barometro-das-diferencas-remuneratorias-mulheres-homens/

DGERT/MTSSS (2020). Ministry of Labour and Social Security. https://www.dgert.gov.pt/ Accessed 12 August 2020.

Diener, E.D., Suh, E.M., Lucas, R.E., \& Smith, H.L. (1999). Subjective well-being: Three decades of progress. Psychological Bulletin, 125(2), 276-302.

Dong, H.J., Larsson, B., Dragioti, E., Bernfort, L., Levin, L.A., \& Gerdle, B. (2020). Factors Associated with Life Satisfaction in Older Adults with Chronic Pain (PainS65+). J Pain Res 13, 475-489.

EUROSTAT (2020). - https://ec.europa.eu/. Accessed 3 June 2020.

INE (2016) Instituto Nacional de Estatística. Inquérito Nacional de Saúde: 2014. www.ine.pt/. Accessed 3 June 2020

INE (2020). Instituto Nacional de Estatistica. National Institute of Statistics. https://www.ine.pt/. Accessed 3 June 2020. 
Judge T.A., \& Watanabe, S. (1993). Another look at the job satisfaction-life satisfaction relationship. Journal of Applied Psychology ,78(6), 939-948.

Loscocco, K., \& Roschelle, A. (1991). Infuences on the quality of work and nonwork life: Two decades in review. Journal of Vocational Behavior, 39, 182-225.

Mónico, L.S., Valente, P., Carvalho, C., Parreira, J., Costa, P., \& Parreira, P. (2019). Emotional intelligence and life satisfaction in adulthood. In García-Alonso, J., \& Fonseca, C. (eds.). Communications in computer and information science (pp.201-215). Springer.

Pavot, W., \& Diener, E. (1993). Review of the satisfaction with life scale. Psychological Assessment, 5, 164-72.

PORDATA (2020). Database for Portugal. https://www.pordata.pt/. Accessed 3 June 2020.

Rain, J.S., Lane, I.M., \& Steiner, D.D. (1991). A current look at the job satisfaction/life satisfaction relationship. Review and future considerations. Human Relations, 44(3), 287-307.

Schaubroeck, J., Ganster, D. C., \& Fox, M. L. (1992). Dispositional affect and work-related stress. Journal of Applied Psychology, 77(3), 322-335.

Silva, R.B. (1998). Para uma análise da satisfação com o trabalho. Sociologia, Problemas e Práticas, 26, 149178.

Unanue, W., Gómez, M.E., Cortez, D., Oyanedel, J.C., \& Mendiburo-Seguel, A. (2017). Revisiting the Link between Job Satisfaction and Life Satisfaction: The Role of Basic Psychological Needs. Frontiers in Psychology, 8 , 680-697. 
